\title{
Quantify Your Self! Numbers in Ambiguous Borderlands of Health
}

\section{Mikka Nielsen \& Lone Grøn}

Hatch \& Bloom, KORA

mikkanielsen@hotmail.com,logr@kora.dk

Nielsen, M \& Grøn, L. (2013). Quantify Your Self! Numbers in Ambiguous Borderlands of Health, Tidsskrift for Forskning i Sygdom og Samfund, nr. 19, 55-74.

This paper explores the widespread use of numbers in health education programs and provides a reflection on the interplay of the medical and moral significance of numbers. Furthermore, the paper points out how patient schools are captured in a borderland space where moral and medical rationalities merge, clash, and collide. Empirical examples from an ethnographic study of six patient schools illustrate different practices where educators and participants reflect and act upon numbers in different ways.

We argue that in the settings of patient schools numbers have become a symbolic form or language that point towards a broad range of natural and cultural phenomena. Drawing on Mattingly's notion of 'moral laboratories' (Mattingly, 2012) we argue that what is to be cultivated in these pedagogical settings are not plants or microorganisms or scientific knowledge, but knowledge of body and self. This knowledge should ideally - if given proper care and guidance - grow strong enough within the confines of the moral laboratory to be able to survive and grow stronger in the participants' everyday lives. Finally we show that even if the use of numbers is being stretched to include not only the medical, but also the psycho-social domain some numbers seem more 'real' than others within this field of practice: The 'phenomenological' or self-assessed numbers, as well as the appliance of numbers to 'human kinds' (Hacking, 1992), is contested and controversial. 


\section{Dansk abstract: Sæt tal på dit selv! Tal i sundhedens ambivalente grænseflader:}

Denne artikel undersøger den mangeartede brug af tal i patientuddannelser og reflekterer over samspillet mellem tals medicinske og moralske betydning. Artiklen beskriver derudover, hvordan patientuddannelser befinder sig $i$ et grænseland, hoor moralske og medicinske rationaler kolliderer og sammenflettes. Empiriske eksempler fra et etnografisk studie af seks patientuddannelser illustrerer forskellige praksisser, hvor undervisere og deltagere reflekterer over og handler ud fra tallene på forskellig vis.

Vi argumenterer for, at tal inden for patientuddannelserne bliver en symbolsk form eller et sprog, der peger på en bred række af naturlige og kulturelle fænomener. Ved at trække på Mattinglys begreb 'moral laboratories' (Mattngly, 2012) argumenterer vi for, at det hverken er planter, mikroorganismer eller videnskabelig viden, der kultiveres inden for disse pædagogiske rammer, men en viden om kroppen og selvet som - hvis den plejes og styres - vil gro tilstrækkelig stærk inden for laboratoriets rammer til at kunne overleve og gro endnu stærkere i deltagernes hverdagsliv. Endelig viser vi, at selvom tallene strækkes til ikke kun det medicinske, men også det psyko-sociale område, synes nogle tal mere 'virkelige' end andre inden for dette felts praksis: De 'fxnomenologiske' eller selvourderede tal, ligesom anvendelsen af tallene på ' human kinds' (Hacking, 1992), er omdiskuteret og kontroversiel.

\section{Introduction:}

I follow the health professional to the room where the participants are measured and where they fill out questionnaires. I ask her what is to be filled out and she responds:" They have to write their name, weight, height, cholesterol level, whether they are married, have employment or are unemployed and such things." She points to the papers while explaining:" Here they have to respond to whether they can manage their everyday lives - on a scale from 1 to 5 - and here if they experience anxiety [also on a scale from 1 to 5]."

In this paper we wish to explore the use of numbers in health education programs. By analysing empirical examples from an ethnographic study of six different patient schools (Grøn et al., 2012) we seek to provide a reflection on the interplay of medical and moral significance of numbers. The use of numbers in health care settings is interesting due to the numbers' status as both real and constructed and both objective facts and actors with moral consequences. Numbers are used as work and direction tools, but they are in no way neutral: in the process of interpreting and understanding what the numbers represent both health 
educators and participants evaluate, experiment with, and act upon the numbers in different ways.

The vignette above takes us into a familiar situation where participants involved in medical or health related interventions are to be measured in different ways in order for the intervention to be able to quantify its successes and failures. Some numbers are meant to measure effect of the program, others are used as background variables characterising participants. In fact, numbers have often been seen in medical settings as pointing towards the domain of the 'natural' in two ways: 1) a biomedical perspective indicating specific diseases and the biomedical body (as in blood glucose and cholesterol levels, kilograms, height, and BMIs) or 2) an epidemiological perspective on distribution of traits and risks in populations. Clearly even within a biomedical perspective numbers have not been seen as 'nature' in and of themselves, but rather as a certain form of abstraction, i.e. a symbolic form, that has come to represent knowledge traditions within the natural sciences. In the vignette, though, numbers are used in other ways, too. Numbers are applied to phenomena related to everyday lives and the emotional interiors of participants. Thus we wish to introduce a vantage point for considering the 'cultural' features of numbers that goes well beyond these biomedical or 'natural' frameworks.

In this paper we will argue that in the settings of patient schools numbers have become a symbolic form or language that can point towards a broad range of natural and cultural phenomena. Drawing on Mattingly's notion of 'moral laboratories' (Mattingly, 2012) we will argue that what is to be cultivated in these pedagogical settings are not plants or microorganisms or scientific knowledge, but a kind of knowledge that - if given proper care and guidance - should ideally grow strong enough within the confines of the laboratory to be able to survive and grow stronger in participants' everyday lives. Finally, we will show that even if the use of numbers is being stretched to include the domain of the psychosocial some numbers seem more 'real' than others within this field of practice: The 'phenomenological' or self-assessed numbers, as well as the appliance of numbers to 'human kinds' (Hacking, 1992), is contested and controversial. 


\section{Health education and patient schools in Denmark in the 21st century}

Group based health education - in a Danish context also referred to as patient schools (even if the terminology is debated ${ }^{1}$ ) - was introduced in Denmark in the 1990s from the US where this type of intervention started up in the 1970s. The first patient schools in Denmark had the reduction of hospital admittance and re-admittance for patients suffering from asthma and diabetes as their goal (Willaing, Folmann \& Gisselbæk, 2005; Maunsbach, 2002; Schnor, 2010). These education programs were hospital based and consisted mainly in nurses passing on the biomedical knowledge they themselves had obtained in their own professional educations (Schnor, 2010; Vedtofte, 2009).

Since then, the field of health education in Denmark has gone through profound developments and transformations. Firstly, health education programs have been developed for a very broad set of diagnoses, often being lumped together under the label of chronic diseases. An influential publication from 2005 lists the following: diabetes type 1 and 2, prostate cancer, kidney diseases, asthma, urological disorders, arthritis and rheumatism, cancer, anticoagulation treatment, eczema, chronic inflammatory bowel disease, osteoporosis, back pain, mental illness, heart diseases, children with epilepsy, children suffering from cancer, and parents of children with eating disorders (Willaing, Folmann \& Gisselbæk, 2005).

Secondly, patient schools have spread to other sectors and organisations than hospitals. Especially due to a sweeping municipality reform in 2007 that had the transferral of hospital based health care tasks to municipalities as one of its main goals, a large number of programs has been created in municipalities - often in collaboration with patient organisations. These expansions in both diagnoses and settings have contributed significantly to the complexity and heterogeneity which is characteristic of this field of practice.

Thirdly, there has been a movement away from the transferral of medical knowledge towards the inclusion of psycho-social themes and methods. The Danish National Board of Health makes a distinction between medico centred and psycho-social approaches in health education (e.g. Sundhedsstyrelsen, 2009) and while this distinction can point towards some differences between schools placed in hospital and municipality settings ${ }^{2}$ it would be more correct to see this distinction as a movement or process in time. As an example Maunsbach listed the central elements that went into health education in Denmark in the following way: knowledge, practical skills, bodily skills, ability to set goals, social competence, 
and emotional and social support (Maunsbach, 2002). This has also meant that the development of health education as a pedagogical - not only a medical - field has become a central task and concern.

Summing up, these developments can be characterised by the words of 'expansion' and 'professionalization', the latter also implying a demarcation from medicine proper - in the effort to make health education a distinct field of expertise. Also these developments have led to the creation of concrete spaces that are characterised by quite fluid boundaries between diverse scientific perspectives and knowledge traditions, between medical and everyday domains of practice, or in the vocabulary of this special issue: between nature and culture.

The fieldwork on which this paper builds was conducted in the autumn of 2010 and involved six patient schools in different organisational settings, targeting specific diseases: cardiovascular diseases, diabetes and COPD as well as the more general 'chronic conditions' (Grøn et al., 2012; Nielsen, 2012). Some were led by health professionals, some by trained expert patients and while there was an overlap of dedication to health pedagogical principles of health promotion, participation, and empowerment, they also covered quite diverse health pedagogical strategies and methods. In each case we followed and participated on equal footing with the other participants in the program from the beginning to the end. After finishing each program we did interviews, both individual and group interviews, with professionals, trained leaders, and participants ${ }^{3}$ asking the patients about the experience of participating in the program and asking the educators about the pedagogical reasoning behind the program.

In the analysis of our data it became apparent how numbers play a significant role in many of the activities and teaching sessions across the six programs. We have selected the empirical examples presented in this paper in order to demonstrate the scope of phenomena to which numbers are applied within this field of practice. The medical numbers applied to biological facts and the self-assessed numbers used to identify exertion level were used in five of the six cases. The example where numbers are used for assessing motivation and future actions only represents one case.

Group based health education - in a Danish context also referred to as patient schools (even if the 


\section{Nature and culture - the real and constructed}

Within medical anthropology the exploration of the nature-culture divide - or maybe more accurately the clash, negotiation, and intermingling of these domains in practice - has had a prominent place for several decades, under headings such as 'medicalization', 'science and technology studies', and 'biosociality'. Special attention has been directed towards the study and critique of how high-tech biomedical perceptions and technologies frame our idea of the human and the social while comparatively less attention has been given to the rise in low-tech technologies of self-care and self-management, which informs the empirical settings of the present paper (Mattingly, Grøn \& Meinert, 2011).

One prominent field in which the nature-culture distinction has been explored is in the study of laboratories instantiated by Latour and Woolgar (Latour \& Woolgar, 1986; Latour, 1987). One of the aims of these laboratory studies has been to challenge the widespread dichotomy between two cultures: the social and the natural science worlds. Arguing instead - through detailed ethnographic fieldwork - that the natural sciences and its products are the end result of a long process of previous activities and that scientific work thereby is not that different from other fields of practice (Olesen \& Kroustrup, 2007). It is also a central point in these studies that the laboratory is something more than just the physical setting in which scientists do their experiments; the laboratory is a setting of knowledge production and carries an epistemological meaning in its own right, and the laboratory is characterised by 'controversies' and 'incomplete knowledge' - not scientific truths and facts (ibid).

This abrogation of the division between the natural and the social sciences is a fundamental argument in Latour's work (See also Latour, 2004; Latour, 1999). Latour criticises how modern traditions like positivism and empiricism legitimise themselves by referring to nature, while postmodern traditions like social constructivism and deconstructionism legitimise themselves by referring to culture. Both positions are thereby equally one-dimensional in their conception of reality as either existing irrespective of - or solely determined by - the eye of the beholder. Nature does not exist a priori, but has been formed through networks of instruments and is defined through the interventions of professionals - it is so to speak cultured in order to become nature. With this follows a discussion of 'construction' versus 'autonomous reality' or 'fabricated' versus 'real' as another made up dichotomy that determinates our way of thinking. "Are scientific facts real or are they constructed?" Latour asks (Latour, 1999: 275). To answer the question Latour 
introduces the concept 'factichs': an antonym of both 'fact' and 'fetish' (Latour, 1999). A factish is neither an independent reality that comes to be discovered in a scientific experiment, nor is it merely the projection of human beliefs onto a neutral object. The concept designates Latour's constructivist ontology where 'reality' and 'construction' are not opposites, but part of the same process.

In regards to health education programs, we find it interesting to see how numbers are both constructed and real. Numbers translate a complex, diffuse, tacit biological condition into a more or less clear-cut indicator that can be taken into account and acted upon, but numbers are also crafted, negotiated and practised in order to invoke or instantiate more low-tech self-care technologies.

\section{The moral laboratory}

In order to move from the high tech biomedical laboratories and the production of scientific facts to the low tech technologies of self care and the cultivation of moral selves, we will explore group based health education and patient schools as moral spaces or more precisely as moral laboratories of health. Drawing on the neo- Aristotelian tradition of virtue ethics, the term 'moral laboratory' has been coined by Cheryl Mattingly as a heuristic term that allows us to investigate moments and spaces where moral deliberations come to take center stage. The trope of the 'moral laboratories' emphasizes how "everyday spaces can become spaces of possibility, ones that create experiences that are also experiments in how life might or should be lived. Each experiment holds its perils. Each provokes moments of critique, especially self-critique" (Mattingly, 2012:12). In our analysis, patient schools are seen as moral spaces where moral selves and tasks are born, where moral work is taught, trained, and perfected and where moral dilemmas and experiments are experienced and set in motion. Here "the participants are not objects of study so much as researchers or experimenters of their own lives - subjects and objects" (Mattingly, 2012: 9).

Summing up we will explore patient schools and health education as borderland spaces, bridging, and merging medical and everyday spaces and matters (Grøn, Mattingly \& Meinert, 2008; Mattingly, Grøn \& Meinert, 2011). More specifically we will explore these settings as moral settings in which bodies, selves, and practices are to be cultivated. While drawing on Latour's deconstruction of the nature-culture distinction and invoking his ethnographic studies of laboratory work, the ethnographic settings of our study are most aptly captured by Mattingly's notion of 'moral laboratories' (Mattingly, 2012) i.e. spaces of moral cultivation. 


\section{Medical and moral numbers}

As mentioned previously, numbers have often been seen in medical settings as pointing towards either a biomedical perspective on specific diseases and the hidden interiors of the body or an epidemiological perspective on distribution of traits and risks in populations. Within these perspectives or traditions the exactness of numbers is highlighted. Such numbers reveal to us the exact blood glucose level or the accurate lung capacity at any given time. Put in charts and statistics, numbers set the standard for normality and make it possible to assess exactly where each individual is located on a scale or a diagram. Therefore, numbers are often the basis for diagnosis and treatment plans. The regimen of numbers and the biomedical approach to the body have been examined from a macro level by numerous social scientists. Foucault, Hacking and Rose all argue how a newfound ability to quantify and define the body using numbers provided a new way of both administrating and thinking about the individual (Foucault, 1995; Hacking, 2007; Rose, 2001). Not only health professionals, but also lay persons incorporate this quantitative understanding of the body when they use different devises to measure and keep track of their health. To illustrate how numbers are present in our way of perceiving individuals, Hacking points to the numerical description of different events in every person's existence from birth to death. From the moment we are born a number is put onto us: our weight. This number "is ritually conveyed to family and friends, announced in the workplace, as a holy number, as if it were the essence of the child" (Hacking, 2002:20). In that way, Hacking writes, the number sets a standard for normality and defines the basis for further development of the child. "Every feature of the child's physical, intellectual, and moral development is to be measured by standards of normalcy"(ibid), Hacking continues and thereby introduces the moral aspect of numbers. Numbers indicate if something is more or less, but also better or worse than something else. Therefore, the number not only represents a numerical value, but also a normative value. The number is bestowed the ability to reflect who we are, in what direction we are heading and how well we behave.

This moral dimension becomes especially clear when we see how numbers are interpreted and given meanings that stretch far beyond the exact value that they were meant to indicate. In his fieldwork among AIDS patients Seeberg (1994) shows how patients interpret and allocate meaning to the numbers measuring different elements in the blood as indicators of how long time they have left to live -as in fact predictors of the future - even if, though, doctors emphasise that these 
numbers cannot be interpreted that way. The number comes to represent pertinent questions for the patients; questions dealing with everyday issues, with what is physically possible, and with life and death. Meinert (2009) also examines this dimension of how numbers are interpreted and associated with the patient's social life. Although the biomedical explanation does not indicate a direct causality between the numbers and the lifespan and social life of the patient, this linkage is made by patients and comes to represent the social reality. Such studies have shown that numbers are not neutral and solely meaningful within a biomedical treatment regimen, but that numbers can become normative devices in patients' pursuit of happiness, health, and the good life.

In the analysis of patient schools we will show that numbers are a symbolic form, a language that can signify or represent phenomena of quite different kinds, be it exact glucose levels, numbers of male diabetics suffering from impotence in Denmark, or indeterminate sensations and possible futures. Also numbers can both be of the 'technological' kind in which devices are necessary in order to determine the exact value of a given phenomenon and of a more 'phenomenological' kind in which self-applied numbers are to indicate the experiential realm and the lived experience of participants. In both cases, numbers are moral actors that reveal essential information and inform practice.

\section{Classifying through numbers}

In the class rooms at the COPD rehabilitation program the participants are taught different kinds of medical and biological numbers. Posters and overheads with illustrations of lungs and tables with numbers and statistics are commonly used as educational materials.

In the following we will see how such numbers not only reveal their factual biomedical content, but also work as a categorising mechanism that reveal whether you belong to a certain category or group of people or not. The measuring and numbering of physiological factors such as blood glucose level or lung capacity places the individual within a diagram and in statistics that define what is normal and what is beyond normal. For most of our informants participation in the patient school is based on numbers. This means that once you have obtained a certain number, you will be referred to a patient school that includes only patients with similar numerical values. Thus, the number is a quantitative representation that identifies whether the individual belongs to a specific group or not. With this subject position a moral task appears: the moral task of caring for the sickness, the 
body, and the self in ways that may not be easily detectible, but that will be revealed through the participation in the program.

At one of the first sessions in the COPD program, the participants are instructed in how to keep an eye on the different numbers that indicate their lung capacity.

"The number you should keep an eye on is called FEV1. It shows how much you can blow within the first second", the nurse says. The table shows both FEV1, something called FVC and FEV1 in percentage. The nurse turns to the whiteboard and writes the following list of numbers: 80-100, 50-80, 30-50, under 30 . While writing she asks the participants who among them belongs to which category and explains that $80-100$ is the mild state of COPD. One of the male participants, Peter, states dryly: "We are all far away from that end of the scale". A few participants belong to the next category 50-80, labelled moderate COPD. Peter comments again: "Then you do not belong here!".

The numbers indicate different levels of COPD. The nurse is explaining to the participants the importance of minding one's numbers and helping them figure out which numbers are relevant and how they should interpret them. The participants look in the booklet that contain their personal numbers, compare their numbers with others', and ask questions. Even though the majority of the participants have been diagnosed with COPD for many years, it seems as if there is still some confusion about what the numbers mean and on what the numbers are based. But regardless of the accurate explanation of each number, it is obvious that the scale is dividing the participants into different categories. Especially Peter notes whether his fellow participants are placed above or below himself on the scale. The lighter end of the scale, it seems, is not relevant for any of them, and for Peter the moderate COPD interval is also well outside his reach. The placement of most participants at the bottom part of the scale has made the seriousness of their predicament palpable in the room. This is a judgment from which they cannot escape. They belong now - and since this is a chronic condition and since this is a number that cannot be improved - for the rest of their lives to this category.

The number defines who you are and is not to be negotiated with. The FEV1 number is simultaneously a detection of prior lifestyle and an indicator of what to expect of the future. Past behaviour that has led to the sickness and possible hopes for the future is implied in this fatal number. Grøn and Vang (2009) have a similar point about numbers as 'tell-tales' as they reflect how well or badly a patient has been behaving. Beyond offering a new way of thinking of the body and administrating individuals, as Rose (2001) argues, the classification presents you with a 
moral task of taking the number seriously and understanding the consequences of the diagnosis.

\section{Experimenting through numbers}

In our second example at a session for diabetics, we see how numbers not only place people within fixed categories, but also how they become avenues for experimentation with everyday actions. In the following example the group has been asked to do an assignment at home: to measure their blood glucose level before and after eating and exercising.

The different measurements show that exercise affects the blood glucose level in a positive way even up until 72 hours after the training session. The health professional sums up the conclusion: that it is better to exercise a little every day than to exercise intensely only twice a week - but you can obviously do both she emphasises. Bodil explains how she had fun measuring the blood glucose level at home. Normally, she is having yoghurt light and a slice of bread for breakfast, but now she tried a white bun with cheese! Her measurement reached 9.2, but after a ride on the bike it was again at the normal level of 7.4. The health instructor responds that this is exactly how they can use the measuring at home: to identify how different food and exercise affect the blood glucose levels. Like with Bodil, the measurements show that she can eat the bun as she is still below 10, but the measurements also reveal that she needs to take a ride on the bike afterwards to reach the desired level. Bodil adds that she was just trying it out and the health instructor concludes that this is exactly how they can get to know themselves.

In this session measuring the glucose numbers opens up a space for experimenting with everyday behaviours. The short-term blood glucose level is malleable as it is highly susceptible to food and exercise. Bodil experiences this changeability during the home assignment and is thrilled by the possibility of directly affecting the blood glucose level. The numbers are not static and fixed, but manageable: Whenever Bodil acts, she herself has the power to have an impact on the numbers. Bodil's experimenting with the numbers is an example of how numbers are transported into a home setting, how they are malleable to everyday behaviour, and how they thereby become avenues of experiments and negotiations. How much can you eat before you need to exercise? And how big an effort are you willing to make for the pleasure of a piece of chocolate? The health instructor emphasises that this is exactly how they "get to know themselves". You can know your num- 
bers without having to go through the labs and the experts, you can experiment with what is possible, you can constantly negotiate your priorities, and, as time goes by, these negotiations and behaviours will become a habitual part of your thinking and behaviour, of "knowing yourself".

\section{Voicing bodily sensations with numbers}

In the following example we turn to the use of scales and illustrate how numbers are used in training sessions. To the observing eye the participants are training their bodies, but a second look reveals how they are simultaneously practicing a new way of assessing, paying attention to, and giving voice to bodily sensations. The biomedical numbers of the previous two examples concern what Drew Leder (1990) denotes as the recessive body, i.e. the inner body of organs and processes that escape our consciousness and will, but to a large extent determines our behaviour, while the numbers in the following example relates to the ecstatic body of perception, motility, and conscious action. Also while the previous numbers were mediated by technology, the following are self-assessed numbers on scales. These numbers on scales differ from the numbers that are measured with instruments since they express the participants' self-perceived experience. The participants have to define, guided by the educators, which number represents the phenomena in question.

At a rehabilitative training session for cardiac patients we see how the Borg scale $^{4}$ is used to identify a specific level for training.

The physiotherapist continues to increase the load [on the exercise bike] and Erik responds that he is beginning to feel the difference in intensity. So far, he has been able to speak, but the speaking gets less and less. When the physiotherapist asks him to read aloud again [from a poster on the wall] and estimate his level of exertion he believes to be around level 11-12. As Erik continues on the exercise bike the physiotherapist encourages him to save his strength and stop speaking. When he reads out aloud again he estimates that he is now at level 13-14: "I think I'm starting to lack air", Erik says. Next time Erik reads, he says "I think we have reached 14 ". He explains how he must stop speaking in order to keep breathing, which indicates level 14-15 on the Borg scale. "I think I can hear your breathing now", the physiotherapist says while she increases the load. When Erik starts reading again the physiotherapist interrupts him: "You do not need to keep reading because you have reached 15 now". 
The test involves both an assessment of the individual's physical endurance and is simultaneously an exercise in quantifying and voicing bodily sensations. During the rehabilitative course Erik has been trained in using the Borg scale. At the end of the course he is beginning to master the technique. He is able to objectify his exertion as he has adopted a numerical language to bodily sensations.

In our material on the use of scales in training sessions we can identify three different purposes of this self-perceived numbering: Firstly, the Borg scale teaches participants to notice how different exercise intensities feel and thereby how to exercise correctly. Secondly, the participants are trained in body awareness and the ability to observe bodily sensations through the use of the Borg scale. When asked to put a number on their exertion the participants need to draw their attention to the body and its signals. As argued by Leder (1990), the body is normally absent from our consciousness, but becomes present whenever we feel pain and in this case exertion. This numeric articulation of the body puts bodily sensations to the centre of the participants' attention in a way that for most participants is new. Thirdly, the measuring and numbering makes it possible for the health professionals to register developments in e.g. breathlessness from test to test. The physiotherapists need to quantify the participants' perception of exertion in order to report their physical capability. By numbering the level of exertion the participant can communicate his or her individually perceived exertion in a numerical terminology that can be translated into a treatment plan. The numbers on scales are »a language that everyone can master if only they can count to 10« (Tørring, 2005: 58), as Tørring writes in her analysis of scales used to assess pain. The use of scales offers a language and can be understood as an attempt to capture an uncanny field between numbers and experience, between biomedicine and phenomenology, between the objective and subjective body.

But the mastering of numbering bodily sensation requires training. Our observations show that numbering bodily sensations is quite challenging and that it requires that the participant understands and accepts the method of numbering. Furthermore, it requires that the participant is able to focus on sensations in the body. Just as learning a new language it takes time to understand the logic and apply the subtle distinctions of numbering. Practicing, feeling one's way and being corrected is an integrated part of the training. 


\section{Predicting and making up futures through numbers}

In our last empirical example numbers are used as indicators of the participants' motivation and future actions through the method of action plans. Based on Albert Bandura's (1995) cognitive psychological theory and his concept of self-efficacy, action plans are used primarily in the Danish version of the American concept 'Chronic Disease Self-Management Program' (CDSMP). The aim of this method or tool is to improve the participants' ability to accomplish a feat. The participants produce actions plans by assessing tasks as more or less possible to accomplish at a scale from 1 to 10 . Then, when actually accomplishing the plan, participants are said to obtain confidence in themselves, and by time they are to adopt this way of operating (setting realistic goals and implementing them) in everyday behaviour. As with the other uses of numbers of the phenomenological kind, which involves self-assessment, these action plan numbers are a language the participants have to learn in order to use them correctly - it requires familiarising and practicing as well as correction from the group leaders. Furthermore, the use of this numerical language requires that you accept the authority of the numbers and of the logic of the method ${ }^{5}$. The following field note from a session, where participants set their action plans for the next week, illustrates how the technique of setting a number can be a tricky task.

Walther is next in line to present his action plan for the following week. "I will do what I regularly do" Walther says with great conviction. "You cannot think of something you would like to have done?" The leader asks encouragingly. "Actually no. I just need to maintain doing what I do", Walther responds and sits back in his chair with his arms crossed. Apparently the group leader does not accept Walther's approach to organising his action plan, but still moves ahead and asks him how confident he is in fulfilling his plan. "Only as confident as the weather allows me to be" Walther responds [Walther suffers from COPD and is heavily affected by humidity]. "But you need to put on a number," the leader tries again and points at the instructions on the wall. "Well, I don't know if you are more in contact with the Lord than I am, but if the weather turns out well, then it is a 10". "Maybe you could say 9 then?" the teacher asks. "If that makes you happy, then 9 it is!" Walther says. The teacher seems confused: “Njaaa ...". “Well then it is 10!” Walther ends the conversation.

Walther has no other plan than to continue walking his daily walk. He is a man of principle, who is very conscious and determined on both training and coping 
with his illness. He has no intentions of setting new weekly goals, which is a requirement of how to work with action plans - each week you have to come up with a new action for your plan. Instead he argues that he will just keep doing what he usually does. Then Walther is asked to set a number on the realism of his plan. Walther is drawing on his past experience when assessing the future - the realism of his plan depends on the weather, he claims. And who can predict that? By drawing in the unpredictable forces of nature Walther succeeds in destabilising the predictive power of numbers.

The use of action plans is inspired by cognitive psychology and deals with the relationship between thought and action. The participants are requested to assess themselves and ask the question: What do I wish for? And what am I capable of? If we consider the number used for the action plans as a sign that is interpreted by the participants the number can be seen as an indication of or a guarantee for the future. If the number is close to ten, the action plan will come true. By imagining a future situation participants are obliged to evaluate their capability, dedication, and self-knowledge: their moral stamina. Participants explain how the commitment makes it embarrassing not to accomplish their goals, which makes the numbering a kind of self-fulfilling prophecy. And then there is Walther, for whom the numbering does not make sense. He does not follow the logic of the numbering and is contesting the authority of numbers by pulling in even bigger forces of nature and the universe. This contesting of the action plans reveals the paradox in the ambition of quantifying action and behaviour. It displays the clash of paradigms between the phenomenology of human actions and the natural science of prediction, between the open-endedness and messiness of human affairs and the stability and reliability of scientific numbers.

And Walter is not alone. In the progression of the analysis we have seen the use of numbers for quite different phenomena: from the inner, recessive body to outer ecstatic body - to apply Leder's terminology - and from these bodies to subtle and indistinct matters of motivation and future actions. What is shared in the use of numbers across these domains is the difficulty of applying and understanding numbers, whether these are mediated by technology or self-assessed. The art of interpreting and applying numbers to body and self takes learning, cultivation, and training.

The trust in or authority behind these different kinds of numbers is markedly different: while most participants might find the biomedical numbers hard to understand, they are rarely questioned, whereas the self-assessed numbers are often contested. "Since these numbers are self-assessed, we can just say anything we 
want", some participants say, thereby criticising the lack of exactness in such numbers. Or in the case of action plans, as remarked by some participants: "You can just lie if you are feeling the group pressure, but have not done your homework". These contestations revolve around exactness and reliability, arguing that such numbers are not 'real' numbers, but fake ones. The use of numbers in action plans has also been challenged from other sides - mainly within the field of health pedagogics - arguing that by applying numbers to matters of the human heart a logic of linearity is invoked that does not apply to such matters and processes of transformation ${ }^{6}$. These diverse strategies to the transformation of 'human kinds' - borrowing Hackings phrase - are in fact one of the main controversies at present in the field of health education in Denmark (Grøn et al., 2012).

\section{Moral laboratories in ambiguous borderlands of health}

In the analysis we have seen how numbers - often associated with biomedicine and the natural sciences - in the settings of patient schools come to take on additional meanings that all imply some kind of moral work, growth, or development. We have argued that in the settings of patient schools numbers have become a symbolic form or language that point towards not only natural, but also cultural phenomena and we have seen that numbers exceed the natural domain in their moral command. Moreover, we have illustrated how numbers create subject positions that carry with them moral tasks and responsibilities. The positions and tasks are to some extent inescapable due to the chronicity of the diseases and due to the way in which the treatment of these diagnoses has been linked to self-care and individual responsibility. If the participants accept and take on these subject positions, the moral tasks involve understanding and experimenting with one's numbers - as in the biomedical and technological numbers, as well as learning to apply phenomenological numbers to bodily experiences, motivations, and future

actions. This moral work by numbers is by no means easy, but it demands training over time. It is also not in any way straight forward, but debated, contested, involving controversies and incomplete knowledge. Using the terminology of Latour, we have seen that numbers become 'inscription devices' (Latour, 1987: 68) which in the context of the patient schools mediate the matters or natures concerned: bodies, sicknesses, souls as well as the goal or end product: the moral self. The inscription quality of the numbers goes far beyond the biomedical domain when they work as phenomenological and moral devices that simultaneously reveal, reflect, and create experiences, emotions, and futures. 
Ethnographic explorations of the nature-culture dichotomy have attested to the illusory or fictive status of the distinction in any pure form in most practical domains, whether it be the scientific knowledge production in laboratories (Latour, 1987; Latour \&Woolgar, 2006; Olesen \& Kroustrup, 2007) or kinship and reproduction - technology assisted or natural (Schneider, 1968; 1980; Carsten, 2004). In the analysis we have shown that deconstruction as a practice of de-legitimisation is practised not only by social scientists, but also by participants in patient schools. But while social scientists might be deconstructing the nature-culture distinction participants seem to be re-instating it. Participants are most often quite serious about numbers of the exact, technological kind, which indicate blood sugar levels and kilograms. Also - if scale numbers of the phenomenological kind actually work, i.e. if participants gain something from learning and applying these scales - there seems to a kind of pragmatic acceptance of their status. But as we have also seen - when it comes to applying numbers to matters governed by the unpredictable forces of the universe and the human heart - participants often openly or secretly question the authority of numbers. While the goal behind broadening the use of numbers to include bodily sensations, motivations, and futures might be the transferral of the exactness, linearity, certainty, and legitimacy that is often afforded the 'biomedical' and 'technological' numbers, the numbers do not in themselves uphold an aura of autonomous reality to them. Some numbers are still more 'real' than others. In this intermediate field of therapeutic and biomedical ambitions the numbers are dominant with more or less success. In fact, when the 'factish' nature of the phenomenological numbers becomes too apparent, they seem to lose their natural authority. So the inscription by numbers is only partially and quite differentially successful.

Also in other ways our analysis part ways with the idea of numbers as inscription devices that create subject positions fraught with moral tasks. Mattingly's notion of 'moral laboratories' allows for a more phenomenological reading of the use of numbers in patient schools. The moral laboratory is the setting in which people create "experiences that are also experiments in what is possible" (Mattingly 2011:4). The participants in patient schools "get to know themselves" when they experiment with the numbers, as one of the health instructors proclaims. In fact, the moral laboratory metaphor highlights several significant features of patient schools: Firstly, it points to the cultivation of self-care within the medical domain as a borderland practice, where moral and medical concerns and rationalities merge, clash, and collide. Secondly, it points to the way in which health education and patient schools are caught between domains and rationalities - a kind 
of ugly duckling which is trying hard to grow into a real swan. In the historical turn in goals and methods in patient schools from transferral of medical knowledge to education in psycho-social and practical self-care, numbers have not been left behind. The messy and highly precarious work of transforming habits, bodies, and selves can borrow some legitimacy through the application of numbers that carry with them an aura of scientific truth and fact. But only to a certain extent. As we have seen, the ambiguousness of the quantification of human kinds gets apparent in the transferral of numbers into the psycho-social domain. Thirdly, it highlights patient schools not only as disciplinary spaces that create subject positions to be taken up or rejected, but as spaces opening up for experiences that are experiments in the possible - both for participants who enter into these laboratories with a sense of promise or hope for change, but also for teachers and facilitators who are constantly trying to ignite such transformative moments and experiences ${ }^{7}$.

\section{Notes}

1. The term patient school is seen by some of the health planners and promoters within this fields of practice as pointing towards a setting in which specific medical knowledge is taught by experts to patients whereas health education is seen as a more collaborative learning process in which professionals serve as guides to participants who are 'experts' in their own lives. Programs based in hospital settings are more likely to use the term school, than those in other settings. We use health education and patient schools interchangeably and do not make a distinction between them.

2. This differences between settings can partly be explained by very different traditions and modes of work and organization in hospitals and municipalities, but has also been politically mandated in relation to the municipality reform where regions, i.e. hospitals were given responsibility for specialized, and municipalities for general patient education and rehabilitation. In the same process a distinction in vocabulary have come to denote the people targeted in these settings, i.e. in hospitals 'patients' are treated and in municipalities 'citizens' are serviced.

3. In total, across the six cases, 177 hours of observation of teaching sessions, 27 interviews with participants and 14 interviews with health professionals have been conducted. Observations and interviews have been equally distributed across the six cases.

4. The Borg scale is a method of rating perceived exertion. Perceived exertion is an individual's rating of intensity, formed by assessing their body's physical signs such as heart rate and breathing rate.

5. For an analysis of the 'logic of change' enacted in the CDSMP - and the program's use of action plans see Juul Nielsen \& Grøn, 2012.

6. As we have already mentioned the use of numbers for the biomedical body and exertion levels is applied in five out of six cases we followed, while the use of numbers in action plans is only used in one case, the CDSMP. While the other five cases are 
placed in both municipality and hospital settings, where they all integrate medical and psycho-social knowledge into their curriculum in different ways, the CDSMP - which is led by expert patients - is only concerned with the psycho- social. And while all the other patient schools we followed had an idea that 'human' or 'cultural' aspects of their curriculum had to be approached in an open-ended way that allowed participants to share, discuss, disagree and learn, a 'phronetic' form of knowledge (Grøn et al., 2012) the strategy of the CDMSP to motivation and behavioral change had more of an instrumental approach to behavioral change.

7. The aim of this article has been to explore the use of numbers in relation to the topic of this special issue: the nature-culture distinction. The distinction between different kinds of moral work, or in Mattingly's words 'moral scenes' of the trial, the workshop and the moral laboratory (Mattingly, 2012), would have highlighted the quite differentiated and complex moral work that takes place in patient schools and involve not only numbers, diagnoses and things medical, but also dancing, joking, eating and other sensual and emotional experiences.

\section{References}

Carsten, J. (2004) After Kinship. Cambridge: Cambridge University Press

Casper, M. \& Koening, B. (1996). Reconfiguring Nature and Culture: Intersections of Medical Anthropology and Technoscience Studies in Medical Anthropology Quarterly. Critical and Biocultural Approaches in Medical Anthropology: A Dialogue Vol. 10 (4). pp. 523-536

Foucault, M. (1995). Discipline and Punishment: The Birth of the Prison, Vintage Books

Grøn, L., Buch M., Nielsen M., Boisen E. \& Rahbæk L. (2012). Egenomsorg og patientuddannelser i grænsefladen mellem medicin og humaniora, DSI rapport. København: Dansk Sundhedsinstitut.

Grøn, L., Mattingly, C. \& Meinert, L. (2008). Kronisk hjemmearbejde. Sociale håb, dilemmaer og konflikter i hjemmearbejdsnarrativer i Uganda, Danmark og USA, Tidsskrift for Forskning i Sygdom og Samfund, vol. 5 (9). pp. 71-95.

Hacking, I. (1992). World-making by Kind-making: Child Abuse for Example. In M. Douglas \& D.Hull (Eds.) How Classification Works. Edinburgh: Edinburgh University Press. pp 180-238.

Hacking, I. (2002). Historical Ontology, Cambridge, Massachussets: Harvard University Press

Juul Nielsen, A. \& Grøn, L. (2012). Standardizing the Lay. Logics of Change in Programs of Disease Self-Management. Culture Unbound, Vol 4, (22).

Latour, B. (1987). Science in Action, Cambridge, Massachusetts: Harvard University Press

Latour, B. (1999). Pandora's Hope: Essays on the Reality of Science Studies, Cambridge, Massachusetts: Harvard University Press

Latour, B. (2004). Politics of Nature: How to Bring the Sciences into Democracy, Cambridge, Massachusetts: Harvard University Press

Latour, B. \& Woolgar, S. (1986). Laboratory Life: The Construction of Scientific Facts. Princeton: Princeton University Press

Leder, D. (1990). The absent body, Chicago: The University of Chicago Press, 
Mattingly, C. (2012). Moral Selves and Moral Scenes: Narrative Experiments in Everyday Life. Ethnos: Journal of Anthropology. pp. 1-27

Mattingly, C., Grøn, L. \& Meinert, L. (2011). Chronic Homework in Emerging Borderlands of Healthcare, Culture, Medicine and Psychiatry, vol. 35 (3). pp. 347-375.

Maunsbach, M.E. (2002). Patientundervisning og patientskoler - idegrundlag og praksis. Ugeskrift for læger. vol. 164 (45). pp. 5269-5277.

Meinert, L., Mogensen H.O. \& Twebaze J. (2009). Tests for Life Chances: CD4 Miracles and Obstacles in Uganda, Anthropology \& Medicine Vol. 16 (2). pp. 195-209

Nielsen, M. (2012): Hvor er I bare nogle gode selvhjælpere - en antropologisk analyse af patientuddannelse som moralsk rum, speciale, Aarhus Universitet

Olesen, F. \& Kroustrup, J. (2007). ANT - Beskrivelsen af heterogene aktør-netværk. In B. Jensen, C. Lauritsen \& F. Olesen (Eds.) Introduktion til STS. Science, Technology, Society, København: Hans Reitzels Forlag.

Rose, N. (2001). The Politics of Life Itself, Theory, Culture \& Society, vol. 18(6) pp.1-22

Schneider, D. M. (1980, 1968): American Kinship. A cultural Account. Chicago and London: The University of Chicago Press

Schnor, H. (2010). Den uddannede patient. In A. M Graubæk (Eds.) Patientolog - at være patient. Gads Forlag, København, pp. 191-210.

Seeberg, J. (1994). Livstegn. En semiotisk analyse af CD4-celletal hos HIV-smittede, Tidsskrift for antropologi, Vol. 29, pp. 39-56

Sundhedsstyrelsen (2009): Patientuddannelse - en medicinsk teknologivurdering, Sundhedsstyrelsen, Monitorering \& Medicinsk Teknologivurdering, København.

Tørring, M. L. (2005): Et skrig af ægte smerte: en antropologisk analyse af tilgange til smerte. Ph.d. afhandling. Antropologi og Etnografi, Aarhus Universitet

Vedtofte, J.I. (2009). Patientskoler - fra forskellige vinkler. In D.I. Vedtofte (Eds.) Pædagogik for sundhedsprofessionelle, Gads Forlag, København, pp. 157-162

Willaing, I., Folmann, N.B. \& Gisselbæk, A.B. (2005). Patientskoler og gruppebaseret patientundervisning - en litteraturgennemgang med fokus på metoder og effekter, Sundhedsstyrelsen, Viden- og Dokumentationsenheden, København 